\title{
EFEKTIVITAS PELATIHAN SELF-MANAGEMENT UNTUK MENINGKATKAN KEDISIPLINAN SISWA SMA N1 SEDAYU
}

\author{
EFFECTIVENESS OF SELF-MANAGEMENT TRAINING \\ TO IMPROVE STUDENTS' DISCIPLINE OF SMA N1 SEDAYU
}

\author{
Sugiarto $^{1}$, Rahma Widyana ${ }^{2} \&$ Nanda Yunika ${ }^{3}$ \\ Program Magister Psikologi Profesi Universitas Mercu Buana Yogyakarta \\ sugiartopsikologi@gmail.com
}

Received: $2^{\text {nd }}$ December 2020; Revised: $21^{\text {st }}$ Januari 2020; Accepted: $2^{\text {nd }}$ February 2021

\begin{abstract}
This study attempts to test empirically effectiveness of self-management training to increase the N1 sedayu high school students.Subject the experiment were 16.8 subject as a group experiment and 8 subject as the control group.Data collection is done likert were 26 of item with 0.776 reliability.Data processing using the different independent sampel t-test.The average score of the experiment 52.12 keolompok control while the 37.25.Thus, it can be concluded that the differences between the the experiment has received special treatment than it is to the control group treatment.The t sample the independent test show the significance, 0.000 value $z=-3.985$ and asymp sig. Smaller than 0.05.This proved that significant increase the differences between the experiment and the control group.
\end{abstract}

Keywords : Training, Self Management, Discipline

\begin{abstract}
ABSTRAK
Penelitian ini bertujuan untuk menguji secara empiris efektivitas pelatihan self-management untuk meningkatkan kedisiplinan siswa SMA N1 Sedayu. Subjek eksperimen berjumlah 16 subyek. 8 subyek sebagai kelompok eksperimen dan 8 subyek sebagai kelompok kontrol. Pengumpulan data dilakukan dengan skala likert berjumlah 26 item dengan reliabilitas 0.776 . Pengolahan data menggunakan uji beda independent sample t-test. Nilai rata-rata kelompok eksperimen sebesar 52.12 sementara keolompok kontrol yaitu 37.25. Dengan demikian, dapat disimpulkan bahwa terdapat perbedaan tingkat kedisiplinan antara kelompok eksperimen yang mendapat perlakuan dibandingkan dengan kelompok kontrol yang tidak diberikan perlakuan. Hasil uji independent sample t test menunjukan hasil signifikansi 0.000 , nilai $\mathrm{Z}=-3.985$ dan Asymp Sig. lebih kecil dari 0.05. Hal ini membuktikan bahwa terdapat perbedaan peningkatan kedisiplinan yang signifikan antara kelompok eksperimen dan kelompok kontrol.
\end{abstract}

Kata Kunci: Pelatihan, Self-management, Kedisiplinan 


\section{PENDAHULUAN}

Proses pendidikan dan pembelajaran di sekolah diharapkan menghasilkan generasi bangsa yang cerdas sesuai amanat Undang-undang. Menurut Undang-Undang Nomor 20 tahun 2003 tentang Sistem Pendidikan Nasional pada Pasal 3, disebutkan bahwa tujuan pendidikan nasional adalah mengembangkan potensi peserta didik agar menjadi manusia yang beriman dan bertakwa kepada Tuhan Yang Maha Esa, berakhlak mulia, sehat, berilmu, cakap, kreatif, mandiri, dan menjadi warga negara yang demokratis serta bertanggung jawab.

Untuk mencapai tujuan pendidikan sesuai amanat Undang Nomor 20 tahun 2003 tersebut, maka sekolah membuat tata tertib di sekolah. Menurut Departemen Pendidikan dan Kebudayaan (1998), tata tertib sekolah adalah peraturan yang mengatur segenap tingkah laku para siswa selama mereka bersekolah untuk menciptakan suasana yang mendukung pendidikan. Sedangkan menurut Soejanto (2005), peraturan tata tertib di sekolah selalu dilengkapi dengan sanksi-sanksi tertentu, yang berpuncak kepada pemberian hukuman. Adanya peraturan itu untuk menjamin kehidupan yang tertib dan tenang, sehingga kelangsungan hidup sosial dapat dicapai. Tata tertib juga berperan mewujudkan kedisplinan siswa. Disiplin berperan penting dalam membentuk individu yang berciri keunggulan. Disiplin sangat diperlukan bagi siswa agar ia memiliki budi pekerti yang baik (Shochib, 2010).

Menurut Njoroge \& Nyabuto (2014), disiplin adalah unsur yang sangat penting bagi keberhasilan prestasi akademik siswa. Disiplin memainkan peran penting dalam pencapaian harapan dan tujuan pembelajaran serta rasa tanggung jawab pada peserta didik serta pendidik. Kedisiplinan harus berjalan efektif disekolah sehingga tujuan pendidikan dapat tercapai. Ehiane (2014) disiplin yang efektif membantu dalam pencapaian tujuan, harapan dan tanggung jawab pada siswa. 
Menurut Drever (2001), disiplin ialah kemampuan mengendalikan perilaku yang berasal dari dalam diri seseorang sesuai dengan hal-hal yang telah diatur dari luar atau norma yang sudah ada. Fathurrohman (2013) menyatakan bahwa disiplin adalah tingkah laku seseorang yang memperlihatkan sikap tertib serta patuh terhadap berbagai ketentuan dan peraturan. Sedangkan menurut Arikunto (2003) disiplin adalah kepatuhan seseorang dalam mengikuti peraturan atau tata tertib karena didorong oleh adanya kesadaran yang ada pada kata hatinya. Kedisiplinan berkaitan erat dengan pengendalian diri seseorang dalam melakukan tindakan secara sadar melalui pembentukan diri dan watak. Lebih lanjut Arikunto (2005) menjelaskan beberapa aspek-aspek kedisiplinan yaitu aspek disiplin di lingkungan keluarga, lingkungan sekolah dan lingkungan pergaulan.

Walaupun peran kedisiplinan sangat penting bagi siswa, namun tidak semua siswa mampu bersikap displin di sekolah. Pada kenyataanya banyak dijumpai siswa di sekolah yang melanggar tata tertib atau tidak disiplin di sekolah. Menurut hasil penelitian Sutrisno (2019) menegaskan bahwa perilaku tidak disiplin siswa ditunjukkan oleh perilaku mereka sehari-hari di sekolah, seperti membolos, datang terlambat, melalaikan tugas, catatan pelajaran tidak lengkap, tidak berseragam lengkap, malas mengikuti pelajaran, acuh tak acuh pada waktu pelajaran, merokok, tidak sopan, mempengaruhi teman untuk melanggar disiplin, nongkrong di warung dekat sekolah, dan bertindak hiperaktif di kelas. Asraf (2015) menegaskan bentuk-bentuk pelanggaran oleh siswa seperti terlambat datang ke sekolah, atribut yang tidak lengkap, tidak masuk sekolah, membolos dan berkelahi. Siswa yang melakukan pelanggaran juga disebut siswa indisipliner atau tidak disiplin (Ariesandi, 2008).

Hasil wawancara pada bulan Maret 2019 di SMA N SEDAYU kepada 17 siswa di SMA Negeri Sedayu yang melakukan perbuatan indisipliner menyimpulkan bahwa terdapat tiga jenis perilaku indisipliner yang sering dilakukan oleh siswa yaitu terlambat datang ke sekolah, tidak mengerjakan tugas rumah (PR) dan tidak memakai 
seragam. Menurut Tu'u (2004) terdapat empat faktor dominan yang mempengaruhi dan membentuk disiplin yaitu kesadaran diri, pengikutan dan ketaatan, alat pendidikan (nilai-nilai yang ditentukan atau diajarkan) dan hukuman. Perilaku siswa terbentuk dan dipengaruhi oleh faktor lingkungan, keluarga dan sekolah (Gunawan, 2014).

Berdasarkan beberapa hasil penelitian terdahulu, terdapat beberapa metode dalam meningkatkan kedisiplinan siswa, antara lain pelatihan self management yang pernah dilakukan dalam penelitian Ardiany (2013). Menurt Corey (2013) konsep dasar selfmanagement dijadikan sebagai intervensi terhadap pengelolaan diri bahwa perubahan dapat dilakukan dengan mengajarkan setiap individu dalam memanfaatkan keterampilan untuk mengatasi situasi yang bermasalah.

Self-management diberikan kepada subyek dengan metode pelatihan. Pelatihan selfmanagement merupakan pendekatan behavior cognitive. Menurut Mulyadi \& Rivai (2009) menyatakan bahwa pelatihan merupakan bagian pendidikan yang menyangkut proses belajar untuk memperoleh dan meningkatkanketerampilan di luar sistem pendidikan yang berlaku dalam waktu yang relative singkat dengan metode yang lebih mengutamakan pada praktik daripada teori.

Metode pelatihan self-management yang akan diberikan dalam peneltian ini merupakan metode pembelajaran yang bertujuan untuk meningkatkan kedisiplinan siswa sesuai dengan aspek-aspek self-management menurut Gie (2000) yaitu pendorongan diri (self motivation), penyusunan diri (self organization), pengendalian diri (self control) dan pengembangan diri (self development).

Pertama, aspek Pendorongan diri (Self Motivation). Motivasi diri merupakan syarat pertama seorang siswa untuk mencapai tujuan pendidikannya. Menurut Gie (2000) pendorongan diri adalah dorongan batin dalam diri seseorang yang merangsangnya sehingga mau melakukan berbagai kegiatan untuk mencapai tujuan yang didambakan. Suatu dorongan 
batin akan kuat kalau timbul dalam diri sendiri, karena diri sendirilah yang akan menentukan terbentuk atau tidaknya self management dalam kedisiplinan.

Kedua, aspek penyusunan diri (self organization). Apabila segala sesuatunya telah diatur sebaik mungkin, maka akan tercapai kehidupan individu menjadi lebih efisien. Menurut Gie (2000) penyusunan diri adalah pengaturan sebaik-baiknya terhadap pikiran, tenaga, waktu, tempat, benda, dan semua sumberdaya lainnya dalam kehidupan seorang siswa sehingga tercapai efisiensi pribadi.

Ketiga, Aspek pengendalian Diri (Self Control. Menurut Chaplin (2011), kontrol diri adalah kemampuan untuk membimbing tingkah laku sendiri dalam artian kemampuan seseorang untuk menekan atau merintangi impuls-impuls atau tingkah laku impuls. Kontrol diri menyangkut seberapa kuat seseorang memegang nilai dan kepercayaan untuk dijadikan acuan ketika bertindak atau mengambil suatu keputusan.

Keempat, aspek pengembangan diri (Self Development). Upaya pengembangan diri peserta didik merupakan suatu aktivitas yang juga menentukan pembentukan kepribadian dan karakter peserta didik dalam rangka mewujudkan perkembangan individu yang optimal (Hulukati, 2013).

Berdasarkan kerangka teoritis yang telah diuraikan diatas, maka hipotesis dalam penelitian ini dapat dirumuskan sebagai berikut :

a. Terdapat perbedaan tingkat kedisiplinan antara kelompok eksperimen dan kelompok kontrol. Setelah mendapatkan pelatihan self-management tingkat kedisiplinan pada kelompok eksperiman lebih tinggi daripada kelompok kontrol yang tidak mendapatkan pelatihan self-management.

b. Ada perbedaan tingkat kedisiplinan pada kelompok eksperimen antara sebelum pelatihan (pretest) dengan setelah pelatihan (posttest). Tingkat kedisiplinan pada kelompok eksperimen lebih rendah sebelum pelatihan dibandingkan setelah pelatihan 


\section{METODE PENELITIAN}

Desain penelitian yang digunakan adalah eksperimen. Metode penelitian eksperimen merupakan penelitian yang dilakukan dengan melakukan manipulasi yang bertujuan untuk mengetahui akibat manipulasi terhadap perilaku individu yang diamati (Latipun, 2010). Dalam penelitian eksperimen, dibedakan pengertian antara kelompok eksperimen dan kelompok kontrol. Kelompok eksperimen adalah kelompok yang diberi perlakuan berupa variabel bebas, sedangkan kelompok kontrol adalah kelompok yang tidak diberi perlakuan apapun atau diberi perlakuan natural (Azwar, 2007). Rancangan penelitian yang digunakan adalah pretest-posttest control group design (Azwar, 2004).

\section{Tabel 1. Desain Penelitian}

\begin{tabular}{|c|c|c|}
\hline NR O1 & X & O2 \\
\hline NR O3 & - & O4 \\
\hline
\end{tabular}

Variabel tergantung dalam penelitian ini adalah kedisiplinan siswa, dan variabel bebas adalah pelatihan self-management. Kedisiplinan siswa adalah kemampuan siswa dalam mengendalikan diri untuk bersikap taat dan patuh sesuai tata tertib dan peraturan yang berlaku karena adanya kesadaran serta dorongan dalam diri. Variabel kedisiplinan siswa diukur dengan menggunakan skala kedisplinan siswa. Skala kedisiplinan dibuat berdasarkan aspek nilai kedisiplinan menurut menurut Arikunto (2005) yaitu pertama aspek disiplin siswa di lingkungan keluarga, meliputi: a) Mengerjakan tugas sekolah di rumah b) Mempersiapkan keperluan sekolah dirumah. Kedua, aspek disiplin siswa di lingkungan sekolah meliputi : a) Sikap siswa dikelas b) Kehadiran siswa c) Melaksanakan tata tertib di sekolah. ketiga, Aspek disiplin siswa di lingkungan pergaulan meliputi : a) Yang berhubungan dengan pinjam 
meminjam b) Yang berhubungan dengan disiplin waktu. Pengujian hipotesis menggunakan uji independent sample t-test dan uji paired sample test.

Subyek penelitian dalam penelitian ini memiliki karakter sebagai berikut:
1. Siswa-siswi SMA Negeri SEDAYU
2. Memiliki skor kedisiplinan rendah dan sedang
3. Belum pernah mendapatkan pelatihan self-management
4. Bersedia menjadi subyek penelitian.

\section{HASIL PENELITIAN}

Dari hasil uji normalitas menunjukan hasil signifikansi uji normalitas dengan shapiro wilk pada kelompok eksperimen (KE) sebesar 0.220 (>0.05) dan kelompok kontrol (KK) sebesar 0.217 (>0.05). Sebaran data penelitian yang digunakan kedua kelompok berdistribusi normal sehingga penelitian ini tetap dapat menggunakan uji independent sample $t$-test guna menguji hipotesis penelitian.

Analisis homogenitas menunjukan pengolahan statistik untuk memenuhi prasyarat uji asumsi independent sample t-test. Hasil menunjukan nilai P $0.898(>0.05)$ yang menunjukan kedua kelompok memiliki varians data yang sama atau homogen.

Hasil uji independent sample t-test didapatkan nilai $\mathrm{P}=0,000$, nilai $\mathrm{Z}=-3,985$. Hal ini menunjukan ada peningkatan yang signifikan antara kelompok eksperimen dan kelompok kontrol. Nilai Asymp Sig. $<0,05$ menunjukan adanya perbedaan antara dua kelompok penelitian. Dari hasil pengolahan data uji t-test yang tertera pada nilai Rank \& Statistic Test diketahui bahwa terdapat perbedaan peningkatan pada nilai rata-rata kelompok eksperimen dan kontrol secara signifikan. Sehingga hipotesis dari penelitian ini diterima, dimana peningkatan kedisiplinan siswa pada kelompok eksperimen yang diberikan pelatihan 
lebih tinggi dibandingkan peningkatan kedisiplinan kelompok yang tidak diberikan perlakuan.

Untuk menguji hipotesis kedua, tentang perbedaan signifikansi antara hasil pretes dan post test pada kelompok eksperimen maka peneliti menggunakan uji paired samples t-test. Paired sample t-test digunakan untuk menguji perbedaan dua sampel yang berpasangan pretets dan postest. Dari hasil uji paired samples t-test dapat diketahui nilai rata-rata pretest sebesar 38.1875 dan nilai rata-rata hasil postest sebesar 44.6875 sehingga dapat diartikan bahwa nilai rata-rata pretest sebesar 38.1875 lebih kecil dibandingkan nilai post test sebesar 44.6875 yang berarti ada perbedaan nilai rata-rata tingkat kedisiplinan antara nilai pre-test dan nilai post-test. Sehingga hipotesis kedua dari penelitian ini diterima, yaitu hasil nilai post test setelah mendapatkan pelatihan lebih tinggi dibandingkan dengan hasil pre test sebelum pelatihan.

Pelatihan manajemen diri dalam penelitian ini, dilaksanakan dengan empat tahapan atau empat sesi pelatihan yaitu 1). tahap self motivation, 2). tahap self organization, 3). Tahap self control dan 4) tahap self development. Setiap tahapan dapat dijelaskan dibawah ini :

Tahapan pertama yaitu self-motivation (motivasi diri). Motivasi diri sangat mempengaruhi perilaku seseorang dalam melakukan suatu perbuatan secara sadar. Motivasi diri berfungsi untuk memunculkan kesadaran dalam diri peserta sehingga mampu meraih tujuan perilaku kedisiplinan (Tu'u, 2004). Ketika seseorang memiliki dorongan motivasi diri yang kuat maka ia akan mampu merubah perilakunya untuk mencapai tujuan yang diinginkan (Gie, 2000).

Tahapan kedua yaitu self-organization (mengatur diri), yaitu pengaturan sebaik-baiknya terhadap pikiran, tenaga, waktu, tempat, benda, dan semua sumber daya lainnya dalam kehidupan seorang siswa sehingga tercapai efisiensi pribadi. Contoh self-organization seperti 
penyimpanan semua dokumen pribadi (dari akte kelahiran, ijazah, dll) dalam berkas-berkas tertentu yang ditaruh pada suatu tempat tertentu pula atau mencatat semua kegiatan yang akan dilakukan pada lembar pengingat yang ditempel di dinding atau papan pengumuman (Gie, 2000). Penyusunan diri untuk tercapainya efisiensi pribadi, pribadi yang efesien tersebut akan menghasilkan perilaku disiplin.

Tahapan ketiga yaitu self-control (kontrol diri). Siswa yang memiliki kontrol diri yang tinggi akan mampu menginterprestasikan setiap stimulus yang diberikan, mempertimbangkannya dan memilih tindakan yang akan dilakukan dengan meminimalkan konsekuensi atau dampak yang tidak diinginkan. Kontrol diri yang dimiliki siswa berhubungan erat dengan kedisiplinan (Tu'u, 2004). Seseorang dengan keterampilan mengontrol diri yang tinggi akan menggunakan waktu dengan tepat dan mengarah pada perilaku yang lebih utama (Aini,. 2011). Untuk melakukan kontrol diri, peserta menyusun jadwal kegiatan harian dirumah. Dengan jadwal tersebut peserta mengontrol dirinya dalam melakukan kegiatan harian. Manfaat jadwal dan kontrol harian yang dibuat siswa merupakan proses yang digunakan siswa untuk memfokuskan pikiran, perasaan, dan tindakan secara sistematis pada pencapaian tujuan (Dale, 2012).

Pada sesi keempat yang merupakan sesi terakhir, diawali dengan ice breaking. Pada sesi ini, peserta telah memahami teknik self motivation, self organization dan self control. Selanjutnya, trainer memberikan materi tentang self devlopment. Menurut Gie (2000) pengembangan diri akan menyempurnakan atau meningkatkan diri sendiri dalam berbagai hal. Dalam hal ini, meningkatkan diri supaya lebih disiplin dalam mengembangkan diri sesuai potensi diri. Dengan menyusun jadwal dan program pengembangan diri, dapat dijadikan acuan siswa dalam berlatih disiplin sehingga terwujud pribadi yang disiplin sesuai aturan yang telah dibuat siswa. Disiplin dapat tercapai dan dibentuk melalui latihan dan kebiasaan (Tu'u, 2004). 
Tabel 2. Tahapan Pelatihan

\begin{tabular}{|c|l|l|}
\hline SESI & \multicolumn{1}{|c|}{ TEMA } & \multicolumn{1}{c|}{ TUJUAN } \\
\hline I & $\begin{array}{l}\text { self-motivation } \\
\text { (motivasi diri) }\end{array}$ & $\begin{array}{l}\text { Peserta mampu membangun motivasi dirinya sendiri } \\
\text { khususnya dalam berpsikap disiplin }\end{array}$ \\
\hline II & $\begin{array}{l}\text { Self } \\
\text { Organization }\end{array}$ & $\begin{array}{l}\text { Peserta mampu merancang program atau jadwal } \\
\text { kedisiplinan dirumah dan di sekolah sesuai aturan yang } \\
\text { berlaku }\end{array}$ \\
\hline III & Self Control & $\begin{array}{l}\text { Peserta mampu mengontrol diri sehingga terbentuk } \\
\text { sikap kedisplinan. Bentuk kontrol diri dengan } \\
\text { menggunakan jadwal harian dirumah dan sekolah }\end{array}$ \\
\hline IV & $\begin{array}{l}\text { Self } \\
\text { Development }\end{array}$ & $\begin{array}{l}\text { Diharapkan peserta mampu menyusun program } \\
\text { pengembangan diri bersikap disiplin jangka panjang } \\
\text { dirumah, disekolah dan di lingkungan sosial }\end{array}$ \\
\hline
\end{tabular}

\section{DISKUSI}

Manajemen diri merupakan salah satu metode intervensi teori cognitive behavior. Menurut Prijosaksono (2002), manajemen diri adalah kemampuan individu untuk mengendalikan sepenuhnya keberadaan diri secara keseluruhan (fisik, emosi, mental atau pikiran, jiwa maupun rohnya) dan realita kehidupannya dengan memanfaatkan kemampuan yang dimilikinya. Manajemen diri dapat bermanfaat bagi kebaikan hidup seseorang. Menurut Harvey (2011), mengemukakan bahwa self-management dapat membantu seseorang untuk bekerja bersama demi kebaikan mereka dari segala masalah yang mereka hadapi, mengajarkan bagaimana cara mengelola segala kondisi yang mereka hadapi serta bagaimana mereka mengatur kehidupannya dalam bersikap dan berperilaku yang efektif di lingkungan tempat tinggalnya.

Dalam penelitian ini, intervensi manajemen diri diberikan dalam bentuk pelatihan secara online melalui aplikasi zoom kepada kelompok eksperimen. Pelatihan manajemen diri pada penelitian ini menggunakan tahapa sesuai pendapat Gie (2000). yaitu: (1), pendorongan diri (self motivation), (2) penyusunan diri (self organization), (3) pengendalian diri (self 
control), (4) pengembangan diri (self development). Seluruh aspek-aspek manajemen diri (self management) tersebut merupakan satu kesatuan yang saling menguatkan. Dengan menerapkan pelatihan self management yang tersetruktur diatas, maka subyek dapat merubah perilaku kedisiplinannya. Dari pembahasan terkait pelatihan, maka diketahui secara singkat proses program manajemen diri dalam pelatihan ini dapat meningkatkan kedisiplinan siswa SMA N1 Sedayu.

Berdasarkan hasil penelitian secara empiris statistik mengenai efektifitas pelatihan manajemen diri untuk meningkatkan kedisiplinan siswa SMA N1 Sedayu Bantul menunjukkan bahwa hipotesis awal terbukti secara signifikan. Hal tersebut dapat diketahui dengan perolehan nilai rata-rata atau mean kelompok eksperimen sebesar 52.125, sementara keolompok kontrol yaitu 37.250. dengan demikian dilihat secara deskriptif statistic dapat disimpulkan bahwa terdapat perbedaan tingkat kedisiplinan antara kelompok eksperimen yang telah mendapatkan pelatihan manajemen diri dengan kelompok control yang tidak mendapatkan pelatihan manajemen diri. Selanjutnya berdasarkan hasil Equal variances assumed diketahui signifikansi sebesar $0.000<0.005$. sehingga dapat disimpulkan bahwa perbedaan kedisiplinan tersebut signifikan atau nyata antara kelompok eksperimen dan kelompok kontrol.

Hasil pretets dan postest pada kelompok eksperimen secara descriptif statistic dapat disimpulkan terjadi perbedaan nilai kedisiplinan. Hal ini terlihat dari hasil uji statistic paired sample test dengan nilai rata-rata atau mean pada pretest sebesar 38.1875 dan nilai mean hasil postest sebasar 44.6875. sehingga dapat diartikan bahwa nilai mean pretest $38.1875<$ post test 44.6875 artinya secara deskriptif terdapat perbedaan rata-rata tingkat kedisiplinan antara nilai pretest dan nilai posttest, dimana nilai rata-rata postest lebih tinggi daripada nilai ratarata pretest. 
Dilandasi hasil pengolahan data maka hipotesis dari penelitian ini diterima dimana peningkatan tingkat kedisiplinan siswa yang diberikan pelatihan manajemen diri lebih tinggi dibandingkan tingkat kedisiplinan siswa yang tidak diberikan perlakuan pelatihan manajemen diri. Diketahui dalam penelitian ini mendapatkan hasil dimana kelompok eksperimen lebih tinggi dibanding kelompok kontrol tingkatan kedisiplinan dirinya setelah diberikan pelatihan manajemen diri atau self management. Pada penelitian sebelumnya oleh Ardiany R., (2013) tentang peningkatan disiplin diri melalui pelatihan Self Management untuk siswa kelas X SMA Negeri 1 Pleret. Hasil penelitiannya menunjukkan bahwa pelatihan self management dapat meningkatkan disiplin diri siswa SMA Negeri 1 Pleret.

Dalam penelitian ini, pelatihan manajemen diri dengan metode online terbukti cukup efektiv untuk meningkatkan kedisiplinan diri siswa. Pelatihan metode online, merupakan hal yang baru dilaksanakan dimasa pendemi virus covid-19. Pada penelitian-penelitian sebelumnya khususnya pada pelatihan manajemen diri, belum menerapkan metode pelatihan secara online. Sehingga pelatihan online dapat diterapkan dalam penelitian selanjutnya.

\section{KESIMPULAN DAN SARAN}

Hasil penelitian secara keseluruhan dapat disimpulkan bahwa tingkat kedisiplinan antara kelompok eksperimen lebih tinggi daripada kelompok kontrol dan terdapat perbedaan rata-rata tingkat kedisiplinan antara nilai pretest dan nilai posttest pada kelompok eksperimen.

Berdasarkan hasil tersebut maka hipotesis dari penelitian ini diterima yaitu terbukti adanya peningkatan kedisiplinan siswa yang diberikan pelatihan self-management yang lebih tinggi dibandingkan kedisiplinan siswa yang tidak diberikan pelatihan self-management.

Bagi siswa, hasil penelitian ini diharapkan mampu mendorong siswa untuk terus meningkatkan kemampuan manejemen diri untuk perubahan perilaku yang lainya baik 
dirumah, sekolah dan lingkungan masyarakat. Hasil penelitian ini juga dapat menjadi salah satu acuan strategi bagi sekolah untuk meningkatkan perilaku disiplin siswa di sekolah. Dengan memberikan sosialisai dan pelatihan self-management bagi siswa. Saran bagi peneliti selanjutnya, hasil penelitian ini hendaknya dapat dijadikan referensi bagi para peneliti yang lain untuk melakukan penelitian lebih lanjut tentang pelatihan online self-management.

\section{DAFTAR PUSTAKA}

Akdon, (2011). Strategi management for educational management. penerbit Alfabeta

Akdon \& Riduwan.(2006). Aplikasi statistika dan metode penelitian untuk administrasi dan manajemen. Bandung: Dewa Ruci

Alamri N. (2015). Layanan bimbingan kelompok dengan teknik self management untuk mengurangi perilaku terlambat masuk sekolah (Studi Pada Siswa Kelas X SMA 1 Gebog Tahun 2014/2015). Jurnal Konseling GUSJIGANG ISSN 2460-1187 vol.1 No.1 tahun 2015.

Allen M. (2013). Michael allen's guide to e-learning. Canada : John Wiley \& Sons

Ambarsari, J. (2017). Efektivitas pelatihan self-management untuk meningkatkan kemampuan belajar dengan regulasi diri (self regulated learning) siswa SMP. Tesis. Program Pendidikan Magister Psikologi Profesi. Fakultas Psikologi. Universitas Muhammadiyah Surakarta.

Ardiany R., (2013) Peningkatan disiplin diri melalui pelatihan Self Management untuk siswa kelas X SMA Negeri 1 Pleret. Jurnal Bimbingan dan Konseling Edisi 3 Tahun ke 2013.

Ardiansyah, I. (2013). Eksplorasi pola komunikasi dalam diskusi menggunakan moddle Pada perkuliahan simulasi pembelajaran kimia, Universitas Pendidikan Indonesia, Bandung-Indonesia

Arikunto S. (2002). Prosedur penelitian suatu pendekatan praktek edisi Revisi V. Jakarta : Rineka Cipta

Arikunto S. (2005). Manajemen penelitian. Jakarta : Rineka Cipta

Ayu, R., F. (2013). Pengaruh pelatihan pelayanan prima terhadap kualitas pelayanan wiraniaga. Tesis. Magister Psikologi Profesi. Universitas Mercu Buana Yogyakarta.

Azwar, S. (2012). Reliabilitas dan validitas.Yogyakarta: Pustaka Pelajar

Bandura, A. (1986). Social foundations of thought and action: A social cognitive theory. New Jerssey: Prentice-Hall.

Budiyani, K \& Martaniah S.M. (2011). Pelatihan self-management untuk meningkatkan kepatuhan diet pada penderita diabetes melitus tipe II. Jurnal PSYCHO IDEA, Tahun 9. 1693-1076.

Chandrawati, S. R. (2010). Pemanfaatan e-learning dalam pembelajaran. Jurnal untan No. 2 
Vol. 8. dari http://jurnal.untan.ac.id/

Chudari I. N. (2016). Program pelatihan pengelolaan diri (self-management) dengan teknik kognitif. Edusentris, Jurnal Ilmu Pendidikan dan Pengajaran, Vol. 3 No. 3.

Cormier, L.J. \& Cormier, L.S. (2009). Interviewing strategies for helpers. 7 ed. Montery, California: Brook/Code Publishing Company

Cormier L.S \& Nurius P. (2003). Interviewing and change strategies for helpers :

fundamental skills and cognitive behavioral interventions. Pacific Grove, CA : Thomson/Brooks/Cole.

Dale H. S. (2012). Learning theories and educational perspective. Yogyakarta: Pustaka Pelajar.

Drever J. (2001). A dictionrry of psychology. New Jersey : Harmondwort Midlesex Penguin Books Ltd.Ehiane, O. S. (2014). Discipline and academic performance (A study of selected secondary schools in lagos, Nigeria). International Journal of Academic Research in Progressive Education and Development. January 2014, Vol. 3, No. 1. ISSN: 2226-6348.

Elly R. (2016). Hubungan kedisiplinan terhadap hasil belajar siswa kelas V di SD Negeri 10 Banda Aceh. Jurnal Pesona Dasar Universitas Syiah Kualah Vol. 3 No.4, Oktober 2016, hal. 43-53 ISSN: 2337-9227.

Fajriani, J. N., \& Loviana D., (2016). Self-management untuk meningkatkan kedisiplinan belajar siswa: studi kasus di SMA Negeri 5 Banda Aceh. .Jurnal Pencerahan Volume 10, Nomor 2, September 2016 ISSN: 1693 - 1775

Fraine \& Geringer. (2000). Principles of personnel management. New York : Mc.Graw Hill Inc.Fathurrohman, P., \& Sutikno S. M., (2013). Pengembangan pendidikan karakter. Bandung: PT. Refika Aditama

Gie, T. L. (2000). Cara belajar yang baik bagi mahasiswa. edisi kedua. \Yogyakarta: Gadjah Mada University Press.

Gunarsa, S. D. (1996). Konseling dan psikoterapi. Jakarta: BPK Gunung Mulia

Gunarsa S. (2006). Psikologi perkembangan anak dan dewasa. Jakarta: Gunung Mulia Harvey P. W. (2011). Self-management and the health care consumer. Nova Science Publishers. New York, N.Y.

Hasibuan W. F., \& Rahadita D., (2017). Faktor penyebab pelanggaran disiplin sekolah pada siswa kelas XII DI SMA 'X' Batam. Jurnal Cahaya Pendidikan, 3(1): 119-132 Juni 2017 ISSN : 1460-4747

Hidayati B.M.R.. (2018). Efektifitas pelatihan self management sebagai upaya meningkatkan self regulated learning siswa kelas VII MTS sunan ampel pare. Journal an-nafs : vol. 3 no. 1.

Indryaningsih, N. L. P., Dharsana, K. \& Suranata, K. (2014). Penerapan teori konseling behavioral dengan teknik self-management untuk meningkatkan motivasi belajar siswa kelas VIII B4 SMP Negeri 4 Singaraja. E-journal Undiksa Jurusan Bimbingan Konseling. 2:1-12

Isnaini, F. \& Taufik. (2015). Strategi self-management untuk meningkatkan kedisiplinan belajar. Jurnal Penelitian Humaniora, Vol. 16, No. 2, : 33-42. 
Komalasari, G., \& Eka W. (2011). Teori dan teknik konseling. Jakarta: Pt Indeks.

Lathan, G.P \& Frayne, C.A. (1990). Increasing job attendance through training in self management: A Review of two Field Experements. Dalam Kleinbeck, U dkk (editor). Work Motivation. Hillsdale : Lawrence Erlbaum Associates.

Tjokro L. S, . (2009). Presentasi yang Mencekam. Jakarta: Elex Media Komputindo

Latipun .(2010). Psikologi eksperimen, Malang : UMM Press.

Martin, G \& Pear, J. (1996). Behavior modification: What It Is And How To Do \It. New Jersey: Prenhell Hall International Inc.

Miltenberger R. G. ( 2012). Behavior modification (principles and procedures). IFifth Edition. USA: Wadsworth Cengange Learning.

Mulyadi \& Rivai (2009). Manajemen sumber daya manusia, Jakarta cetakan kesembilan

Neitzel, J \& Busick, M. (2009). Overview of self-management. Chapel Hill, NC:

Nursalam. (2003). Konsep dan penerapan metodologi penelitian ilmu keperawatan. Jakarta : Salemba Medika.

Njoroge, Philomena M., \&Ann N. N. (2014). Discipline as a factor in academic performance in Kenya. Journal of educational and social research. (Online). Vol.4 No.1.Tersedia:http://www.mcser.org/journal/index.php/jesr/article/view/1847

Pranoto \& Alvini., (2009). Sains dan teknologi. Jakarta: PT Gramedia Pustaka Utama Prayitno. (2004). Dasar-dasar bimbingan dan konseling. Depdikbud: Rineka Cipta

Prijosaksono, Aribowo \&Marlan M. (2001). 12 Langkah self-management. Jakarta : Elex Media Computindo.

Retnowulan D. A. \& Waristo H. (2013). Penerapan strategi pengelolaan diri (self management) untuk mengurangi kenakalan remaja korban broken home. Jurnal BK Unesa. Volume 03 Nomor 01 Tahun 2013. 335-340

Rokke, P. D. \& Rehm, L. P. (2001). Self-management therapies. Dalam Dobson, K.S. (Penyunting), Handbook of cognitive behavioral theapies. Second edition. New York: The Guilford Press

Sastradipoera, K., (2006). Strategi pembangunan sumber daya berbasis pendidikan kebudayaan. Bandung : Kappa Sigma

Sulistyo, G. \& Mulyono, A., (2004). Kamus lengkap bahasa indonesia. Surakarta : Penerbit Ita.

Supriyanto, A., (2013). Mengatasi Perilaku Terlambat datang ke sekolah Melalui Konseling Individual Pendekatan Behavioristik dengan teknik Behavior Shaping di SMP Negeri 19 Semarang Tahun Ajaran 2011/2012. online(http://lib.unnes.ac.id/12088, diakses Agustus 2014

Sugiyono, (2013). Metode penelitian kuantitatif, kualitatif dan R\&D. Cetakan Ke-19, Penerbit Alfabeta, CV. Bandung

Sutrisno, H. (2009). Kasus perilaku pelanggaran disiplin siswa di sekolah ditinjau dari kerangka teori sosiologi fungsionalisme. Jurnal Pendidikan Edukatif, Jilid 4, Nomor 2 . 
Tu'u T., (2004). Peran disiplin pada perilaku dan prestasi siswa. Jakarta: PT. Gramedia Widiasarana Indonesia

Wahyuningtyas J. (2018). Hubungan self-management dengan kedisiplinan siswa kelas XI

SMA Negeri 1 Kediri tahun ajaran 2017/ 2018. Simki-pedagogia vol. 02 no. 02 tahun 2018 issn : 2599-073x

Wahyudi M.A.S, (2016). Pendekatan behavior dalam menangani perilaku indisipliner siswa korban perceraian di SMP Diponegoro, Yogyakarta. Jurnal Analisis, Volume XVI, Nomor 2, Desember 2016.

Wahyaningrum A., Muslim M., \& Hidayat R.R. (2017). Teknik self management untuk meningkatkan kemandirian belajar siswa MTs. CONSILIUM : Jurnal Program Studi Bimbingan dan Konseling First Published Vol 5 (2) June 2017.

Wibowo, M.E. (2005). Konseling kelompok perkembangan. Semarang: UNNES Press

Wirantasa U. (2017). Pengaruh kedisiplinan siswa terhadap prestasi belajar matematika. Universitas Indraprasta PGRI. Jurnal Formatif 7 (1): 83-95, Yoyo, T. (2007). Self-management budhis. Yogyakarta : Insight Zuriah N. (2011). Pendidikan moral dan budi pekerti dalam perspektif perubahan. Jakarta: Bumi Aksara. 